\title{
REVIEW PAPER \\ Paleopathology of SOFT Tissues: WHAT MUMMiES CAN REVEAL
}

Pedro L. Fernández ${ }^{1}$, Jordi Esteban², Agustín Franco ${ }^{3}$

\begin{abstract}
${ }^{1}$ Department of Pathology, Hospital Germans Trias i Pujol and Universidad Autonoma de Barcelona, Badalona, Spain ${ }^{2}$ Department of Pathology, Hospital Clinic, Barcelona, Spain

${ }^{3}$ Department of Urology, Hospital Clinic and University of Barcelona, Barcelona, Spain
\end{abstract}

\begin{abstract}
Paleopathology is a science located in a crossroad between history, archaeology, anthropology, and medicine an can offer unique historical knowledge by using techniques of traditional pathology as well as other branches of Medicine, which is especially fruitful when applied to ancient subjects in which soft tissues are preserved: mummies.
\end{abstract}

Key words: paleopathology, mummy.

The history of medicine is usually based on written historical records [1], but sometimes ancient subjects are actually sufficiently preserved over long periods of time, and upon discovery, provide an amazing wealth of valuable direct evidence of both diseased human remains, and more rarely, medical procedures.

Paleopathology is a discipline situated at a most interesting crossroad between history, archaeology, anthropology and medicine, being therefore in a unique position to blend different approaches to obtain historical knowledge.

Among ancient remains, the most frequent are those consisting of bony samples, sometimes including full skeletons. These durable samples can sometimes contain remnants of diseases such as neoplasms, degenerative processes or even infections which usually involve bones. Unfortunately, most human conditions do not affect bony tissue and remain undiscovered after careful analysis of bones.

Mummies are ancient human or animal remains in which outer or inner soft tissues are, to some extent, artificially or naturally preserved (Fig. 1). This usually occurs by a rapid desiccation process, although in some instances humid environments allow other types of soft tissues preservation [2]. The amount and quality of possible samples obtained from mum- mies require the adoption of a multidisciplinary approach [3] including not only anthropology and possibly archaeology but also several sophisticated areas of medicine such as pathology, microbiology, paleonutrition, molecular biology, etc.

\section{History of paleopathology}

It is known that Herodotus studied ancient mummification rites in Egypt, and that, more recently, Virchows had the opportunity to analyze mummified subjects [4]. However, it was great scholars such as Elliot Smith, Ruffer, Zimmerman and Aufderheide who definitively provided the scientific bases for the development of paleopathology as a modern science $[4,5,6]$. A good, recently published summary of the history of paleopathology mentions that the term "paleopathology" was not coined until 1892 by R. W. Schufeldt [7]. The technical advances for the histological processing of mummified tissues provided by Sir Armand Ruffer and Sandison [8, 9]. were paramount for the study of soft tissues. During the last part of the XX and the ongoing XXI century, seminal and extensive work in paleopathology, and more specifically, in mummified subjects, was undertaken by Aufderheide and Rodriguez-Marin [4, 5], 


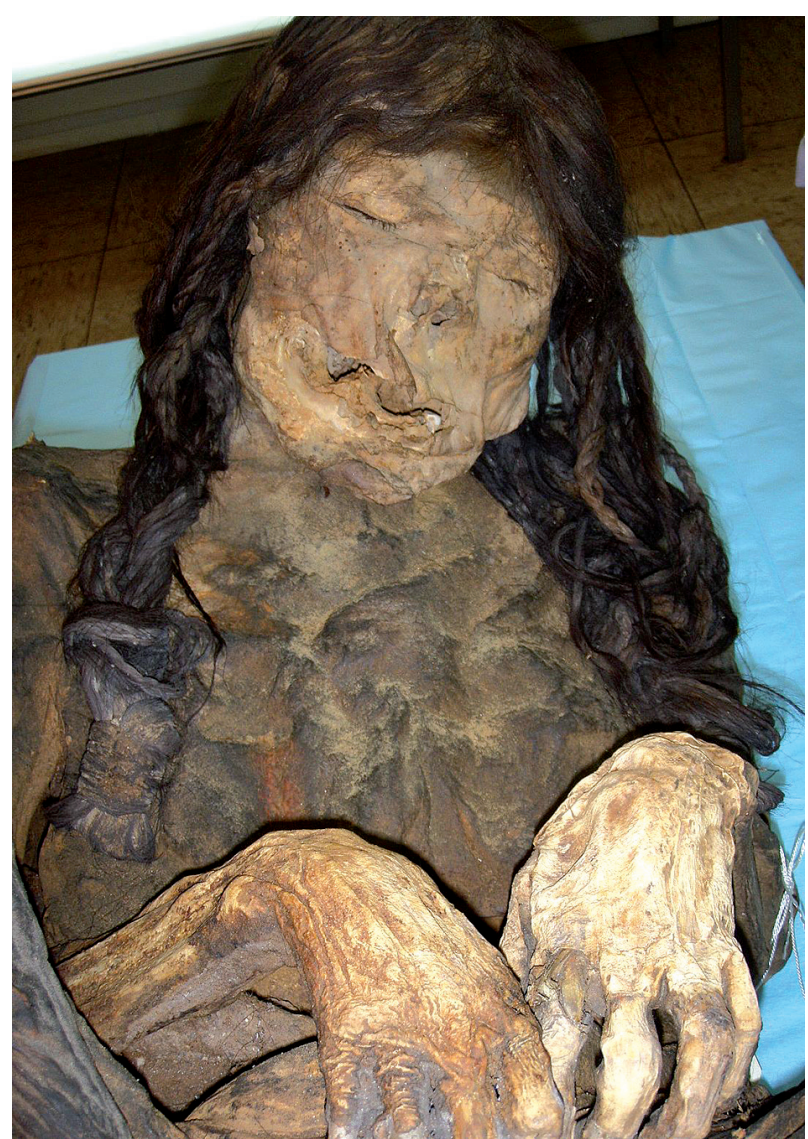

Fig. 1. Mummified woman from ChiuChiu, Atacama Desert (Bolivia). Date unknown. Collection of the Museum of the Department of Legal Medicine, Universidad Complutense de Madrid, Spain

Fornaciari [10] and Gerszten and Allison from the Medical College of Virginia [11, 12], although several other groups have provided interesting contributions to this field [see references 6,7 and 13 for a review].

\section{Methods used in paleopathology}

The term paleopathology has traditionally been related to physical anthropologists given their experience dealing with bony remains. However, the appearance of mummified soft tissues is frequently neglected as an important source of information about human diseases that leave no trace in skeletal remains. In fact, it was a common practice to strip bones of these soft components in order to achieve better access to morphological information from them. Mummies, like any other remains, can have different degrees of preservation, in part depending on the mummification process. Thus, preservation of outer parts of the body like skin and muscles of artificial mummies from ancient Egypt is very good but the inner organs are often lacking due to the classical practice of evisceration. Also, the use of ointments for better preservation produces artefacts in these subjects that hamper histological examination. Other artificial mummies such as those of the Chinchorro culture, are possibly the oldest known and are difficult to interpret since their preservation was based on stripping soft tissues, disarticulation of bones and ulterior articulation and covering with colorful clays [14]. Some of the best preserved subjects were naturally mummified by rapid cold desiccation, such as the Tyrol man $[15,16]$ or the Andean child mummies [17].

When approaching a mummified subject, the first question is if the degree of preservation is good enough to allow a meaningful study, and this decision is usually based on the extent of soft tissue preservation, the experience of the "paleopathologist" and, finally, the success of the histopathological examination. Another important question is to what extent the mummy can be "harmed" by extraction of its information. For instance, can a full autopsy be performed? Can only small superficial biopsies be obtained? Must the subject be "reconstructed" after the autopsy for exposition?, etc. And, very importantly, the possibility of non-invasive techniques such as conventional radiology, computerized tomography or even magnetic resonance studies $[18$, 19,20 ] should be considered, although the latter is not the best study technique in dried specimens. In some instances, the use of minimally invasive procedures such as endoscopy using a flexible cystoscope or a flexible fibrogastroscope can provide very useful images and samples $[21,22]$.

Once the soft tissue is obtained, a technical procedure similar to that used in conventional samples of fresh tissue can be followed: formalin fixation, paraffin embedding, microtome sectioning and histochemical staining. Nonetheless, all of this is only possible if we first return the tissue to a rehydrated state with the use of some simple solutions like those

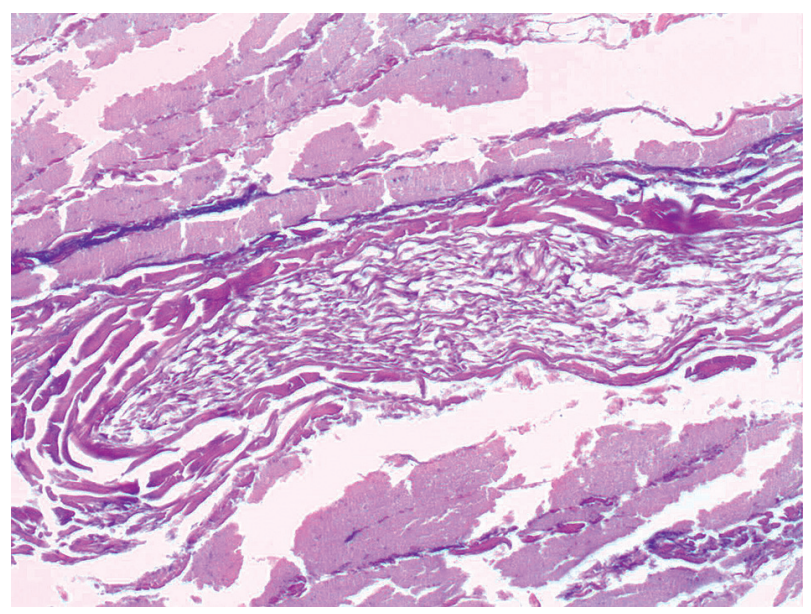

Fig. 2. Nerve fascicle (center) surrounded by perineuro and skeletal muscle. HE staining, magnification $200 \times$ 


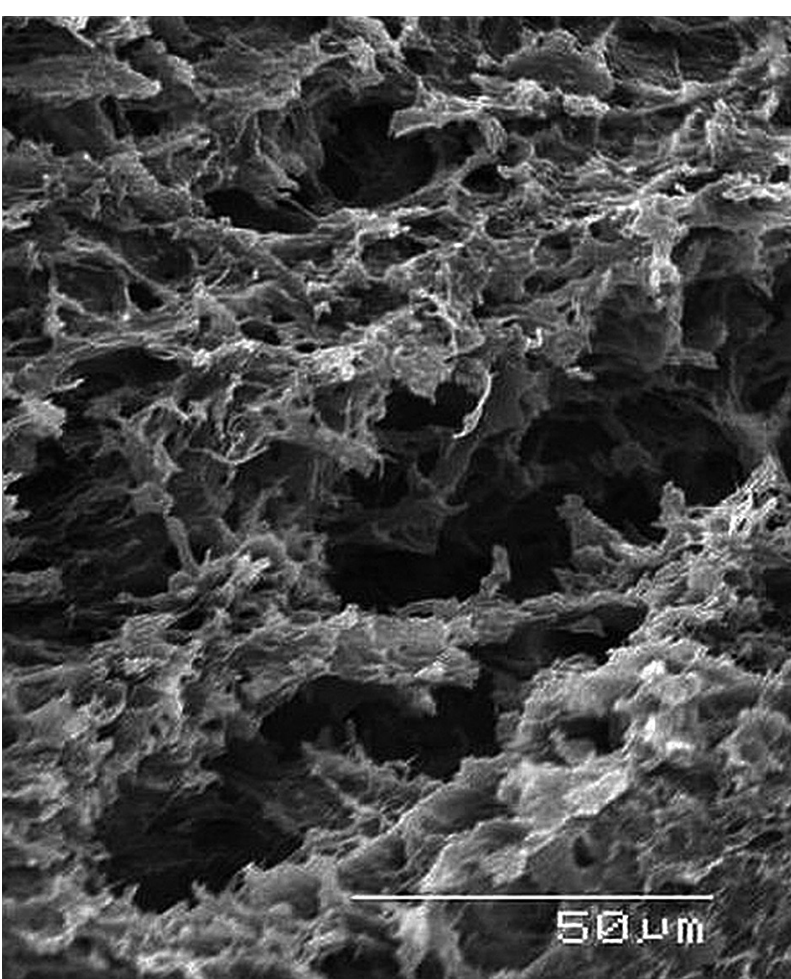

Fig. 3. Scanning electron microscopy of white matter from mummified Bronze Age brain tissue [25]

of Ruffer or Sandison, which are mainly based on an alcoholic solution with sodium carbonate $[8,9$, 23, 24].

Samples processed in this way can be then analyzed with light or even electron microscopy [25] (Figs. 2, 3). Moreover, if tissue preservation is relatively good, immunohistochemical staining and molecular tests are also possible (Fig. 4) $[23,26,27,28$, 29]. Recently, advances in proteomics have succeeded in identifying several proteins related to immune response and inflammation in mummified tissue samples, thus providing evidence of active pathogenic infection related to the cause of death [30].

\section{Pathology in mummies}

Different types of pathological conditions have been reported in mummies, including both neoplastic and non-neoplastic diseases. Apart from osseous evidence of malignancies and benign tumors [31, 32], several types of neoplasms such as histiocytomas, adenocarcinomas and metastases have been described in mummified tissues [6, 33-37]. Malignant neoplasms are scarce in paleopathological studies, probably due to a variety of causes including the absence of chemical environmental contamination leading to less carcinogenic exposure, shorter life expectancy or simply the disappearance of tissue evidence given the frequent origin in and involvement of soft tissues $[6,36,38,39]$. Contrarily to cancer, infectious

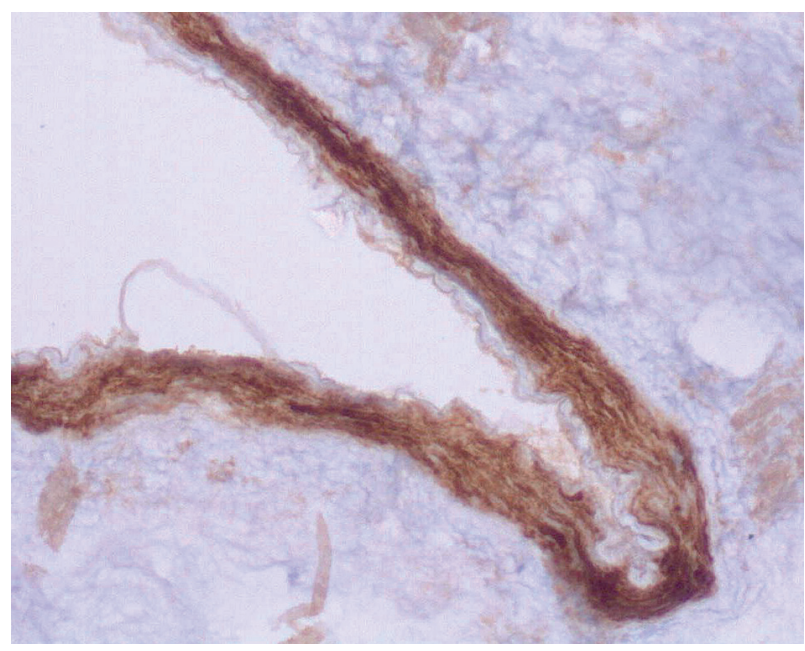

Fig. 4. Positive immunohistochemical staining for actin in a renal vascular wall of an Andean mummy (approximately 500 years old). Hematoxylin/DAB, magnification $200 \times$

diseases such as tuberculosis and treponematosis in ancient Egypt and, Helicobacter pylori, malaria, smallpox and different types of parasitic diseases [40-46] in the pre-Columbian New World are abundant in the literature. Other conditions have been described in mummies, including degenerative bone processes in South American mummies indicating the high prevalence of vertebral degenerative changes and the scarcity of metastases to bone in this area [47] as well as some endocrine pathologies including goitre [48], tissue deposits as in pneumoconiosis [49] or gout [50] and acquired, heritable, nutritional or hormonal skin disorders [51].

\section{Seminal studies in paleopathology}

There have been many important paleopathological studies since the first in the XIX century, therefore, a review of previous extensive studies in paleopathology would be of great interest $[4,5,6]$. The special relevance of some paleopathological studies may lie in the technical advances applied to this discipline, the discovery of relevant pathological conditions from a medical point of view in a historical context in "common" subjects or in the analysis of famous historical subjects irrespective of the interest of the findings.

Elliot Smith, Ruffer and Lucas performed extensive breakthrough studies in a large number of Egyptian mummies which were the starting point of the scientific development of the field of paleopathology [see 4,5 for a review]. As mentioned previously, technical developments such as the fixation methods by Ruffer and Sandison, pioneer molecular approaches for the study of genetic material by Pääbo [26], the multidisciplinary approach to the study of the Tyrolean Iceman $[15,16,49]$, and similarly, well preserved 
subjects such as the Artic and bog mummies [2, 52] have fuelled the extraction of a massive amount of relevant information from paleopathological projects on "commoners".

There have been important medical discoveries in subjects of historical relevance, usually from royal families. For instance, according to the microscopic and molecular results provided by Marchetti et al. [35], Ferrante I of Aragon, the King of Naples during the XV century, most likely died of colorectal cancer. Indeed, to our knowledge, this was the first bona fide molecular demonstration of a malignant neoplasm in an historical mummy. Similarly, the death of Francesco I of Medici by malaria and the severe gout of Emperor Charles V of Augsburg, most likely influenced some historical events during the XVI century $[50,53]$. Indeed, it is within the context of the capacity of paleopathology to provide explanations related to the health of historical subjects who potentially influenced historical events that this discipline acquires special relevance. Nevertheless, at times it is the systematic study of anonymous populations which provides critical insights into the history of medicine, a clear example being the now demonstrated fact that tuberculosis existed in South America before the arrival of the conquistadors [54].

Thus, there have been many reports on paleopathological studies in mummies, but only a few have attracted intensive media coverage due to the importance of the subjects studied or the impact of the discoveries from a strictly scientific point of view. The exhaustive analysis of the Tyrolean man and the diseases affecting Tutankhamun and his possible cause of death $[55,56]$ have been widely covered by the media and have attracted special attention to paleopathology. Likewise, the scientific studies of the mummified cardiac remains of Richard the Lionheart provided renewed interest in this famous monarch [57].

In summary, paleopathology is a medical discipline that combines several approaches (historical, anthropological, archaeological and medical) for the study of ancient remains, with special interest in mummified tissues. In addition, this discipline poses technical and intellectual challenges which can produce very interesting knowledge for better understanding the evolution of disease and medicine and their impact along human history.

The authors declare no conflict of interest.

\section{References}

1. Mitchell PD. Improving the use of historical written sources in paleopathology. Int J Paleopathol 2017; 19: 88-95.

2. Lynnerup N. Bog bodies. Anat Rec (Hoboken) 2015; 298: 1007-1012.
3. Buikstra JE, Cook DC, Bolhofner KL. Introduction: Scientific rigor in paleopathology. Int J Paleopathol 2017; 19: 80-87.

4. Aufderheide AC, Rodriguez-Martín C. History of Paleopathology. In: Aufderheide AC, Rodriguez-Martín C (eds.). The Cambridge encyclopaedia of Human Paleopathology. Cambridge University Press, Cambridge 1998; 1-7.

5. Aufderheide AC. History of mummy studies. In: Aufderheide AC (ed.). The scientific study of mummies.Cambridge University Press. Cambridge 2003; 1-17.

6. Lynnerup N. Mummies. Am J Phys Anthropol 2007; Suppl 45:162-190.

7. Grauer A. A century of paleopathology. Am J Phys Anthropol 2018; 165: 904-914

8. Ruffer MA. Pathological notes on the royal mummies of the Cairo museum. In: Studies in the Paleopathology of Egypt. Moodie RL (ed.). Univ. of Chicago Press, Chicago 1921; 166-178.

9. Sandison AT. The study of mummified and dried human tissues. In: Sciencie in Archeology. Brothwell D, Higgs E (eds.). London, Thames and Hudson, London 1963; 413-425.

10. Fornaciari G. Histology of ancient soft tissue tumours: A review. Int J Paleopathol 2018; 21: 64-76.

11. Allison MJ, Bergman T, Gerszten E. Further studies on faecal parasites in antiquity. Am J Clin Pathol 1999; 112: 605-609.

12. Gerszten E, Allison MJ, Maguire B. Paleopathology in South American mummies: a review and new findings. Pathobiology 2012; 79: 247-256.

13. Fernández PL. Paleopathology: the study of disease in the past. Pathobiology 2012; 79: 221-227.

14. Aufderheide AC, Muñoz I, Arriaza B. Seven Chinchorro mummies and the prehistory of northern Chile. Am J Phys Anthropol 1993; 91: 189-201.

15. Seidler H, Bernhard W, Teschler-Nicola M, et al. Some anthropological aspects of the prehistoric Tyrolean ice man. Science 1992; 258: 455-7

16. Hess MW, Klima G, Pfaller K, et al. Histological investigation on the Tyrolean Ice Man. Am J Phys Anthropol 1998; 106: 521-532.

17. Wilson AS, Brown EL, Villa C, et al. Archaeological, radiological, and biological evidence offer insight into Inca child sacrifice. Proc Natl Acad Sci U S A 2013; 110: 13322-13327.

18. Rühli FJ, Chhem RK, Böni T. Diagnostic paleoradiology of mummified tissue: interpretation and pitfalls. Can Assoc Radiol J 2004; 55: 218-227.

19. Giovannetti G, Guerrini A, Carnieri E, et al. Magnetic resonance imaging for the study of mummies. Magn Reson Imaging 2016; 34: 785-794.

20. Romell J, Vågberg W, Romell M, et al. Soft-Tissue Imaging in a Human Mummy: Propagation-based Phase-Contrast CT. Radiology 2018; 289: 670-676.

21. Franco A, Esteban J, Cañas-Gálvez F de P, et al. Paleoendoscopy: the paleopathological study of Sancho's mummy, son of king Pedro I of Castilla The Cruel (XIV century). Med Clin (Barc) 2012; 138: 37-40

22. Beckett RG. Application and limitations of endoscopy in anthropological and archaeological research. Anat Rec (Hoboken) 2015; 298: 1125-1134.

23. Lynnerup N. Methods in mummy research. Anthropol Anz 2009; 67: 357-384.

24. Grove C, Peschel O, Nerlich AG. A Systematic Approach to the Application of Soft Tissue Histopathology in Paleopathology. Biomed Res Int 2015; 2015: 631465

25. Prats-Muñoz G, Malgosa A, Armentano N, et al. A paleoneurohistological study of 3,000-year-old mummified brain tissue from the Mediterranean bronze age. Pathobiology 2012; 79: 239-246.

26. Pääbo S. Molecular cloning of Ancient Egyptian mummy DNA. Nature 1985; 314: 644-645. 
27. Fulcheri E. Immunohistochemistry: a new outlook in histopaleopathology. Boll Soc Ital Biol Sper 1995; 71: 105-110.

28. Nerlich AG. Molecular paleopathology and paleo-oncology-State of the art, potentials, limitations and perspectives. Int J Paleopathol 2018; 21: 77-82.

29. Anastasiou E, Mitchell PD. Paleopathology and genes: investigating the genetics of infectious diseases in excavated human skeletal remains and mummies from past populations. Gene 2013; 528: 33-40.

30. Jones J, Mirzaei M, Ravishankar P, et al. Identification of proteins from 4200-year-old skin and muscle tissue biopsies from ancient Egyptian mummies of the first intermediate period shows evidence of acute inflammation and severe immune response. Philos Trans A Math Phys Eng Sci 2016; 374 : 20150373.

31. Campillo D. Introducción a la paleopatología. Ediciones Bellaterra, Barcelona 2001.

32. Ghabili K, Tosoian JJ, Schaeffer EM, et al. The History of Prostate Cancer From Antiquity: Review of Paleopathological Studies. Urology 2016; 97: 8-12.

33. Zimmerman MR. A possible histiocytoma in an Egyptian mummy. Arch Dermatol 1981; 117: 364-365.

34. Grevin G, Lagier R, Baud C. Metastatic carcinoma of presumed prostatic origin in cremated bones from the first century A.D. Virchows Arch 1997; 431: 211-214.

35. Marchetti A, Pellegrini S, Bevilacqua G, et al. K-ras mutation in the tumour of Ferrante I of Aragon, King of Naples. Lancet 1996; 347:1272

36. Nerlich AG, Rohrbach H, Bachmeier B, et al. Malignant tumours in two ancient populations: An approach to historical tumour epidemiology. Oncol Rep 2006; 16: 197-202.

37. Fornaciari G, Giuffra V. Soft tissue tumours in Paleopathology: a review. Pathobiology 2012; 79: 257-267.

38. David AR, Zimmerman MR. Cancer: an old disease, a new disease or something in between? Nat Rev Cancer 2010; 10: 728-733.

39. Gaeta R, Giuffra V, Fornaciari G. Cancer in the Renaissance court of Naples. Lancet Oncol 2017; 18: e432.

40. Zink AR, Sola C, Reischl U, et al. Characterization of Mycobacterium tuberculosis complex DNAs from Egyptian mummies by spoligotyping. J Clin Microbiol 2003; 41: 359-367.

40. Ziskind B, Halioua B. Tuberculosis in ancient Egypt. Rev Mal Respir 2007; 24: 1277-1283.

41. El-Najjar MY. Human treponematosis and tuberculosis: evidence from the New World. Am J Phys Anthropol 1979; 51: 599-618.

42. Castillo-Rojas G, Cerbón MA, López-Vidal Y. Presence of Helicobacter pylori in a Mexican Pre-Columbian Mummy. BMC Microbiol 2008; 8: 119.

43. Nerlich AG, Schraut B, Dittrich S, et al. Plasmodium falciparum in ancient Egypt. Emerg Infect Dis 2008; 14: 1317 1319.

44. Aufderheide AC, Salo W, Madden M, et al. A 9,000-year record of Chagas' disease. Proc Natl Acad Sci U S A 2004; 101: 2034-2039.

45. Allison MJ, Pezzia A, Hasegawa I, et al. A case of hookworm infestation in a Precolumbian American. Am J Phys Anthropol 1974; 41: 103-106.

46. Gerszten PC, Gerszten E, Allison MJ. Diseases of the spine in South American mummies. Neurosurgery 2001; 48: 208-213.

47. Green RE, Krause J, Briggs AW, et al. Goiter in an eighteenth-century Sicilian mummy. Am J Phys Anthropol 1999; 108: 427-432

48. Pabst M, Hofer F. Deposits of Different Origin in the Lungs of the 5,300-Year-Old Tyrolean Iceman. Am J Phys Anthropol 1998; 107: 1-12.
49. Ordi J, Alonso PL, de Zulueta J, et al. The severe gout of Holy Roman Emperor Charles V. N Engl J Med 2006; 355: 516520.

50. Lowenstein EJ. Paleodermatoses: lessons learned from mummies. J Am Acad Dermatol 2004; 50: 919-936.

51. Zimmerman MR, Aufderheide AC. The frozen family of UtqiagviK: the autopsy findings. Artic Anthropology 1984; 21: 53-64.

52. Fornaciari G, Giuffra V, Ferroglio E, et al. Malaria was "the killer" of Francesco I de Medici (1531-1587). Am J Med 2010; 123: 568-569.

53. Mackowiak PA, Blos VT, Aguilar M, et al. On the origin of American tuberculosis. Clin Infect Dis 2005; 41: 515-518.

54. Hawaas Z. Tut's family secrets. Nat Geographic 2010; 218 : 34-59.

55. Hussein K, Matin E, Nerlich AG. Paleopathology of the juvenile Pharaoh Tutankhamun-90th anniversary of discovery. Virchows Arch 2013; 463: 475-479.

56. Charlier P, Poupon J, Jeannel GF, et al. The embalmed heart of Richard the Lionheart (1199 A.D.): a biological and anthropological analysis. Sci Rep 2013; 3: 1296.

\section{Address for correspondence}

\section{Pedro L. Fernández,}

Department of Pathology

Hospital Germans Trias i Pujol

and Universidad Autonoma de Barcelona,

Badalona 08916, Spain

tel. +34934978853

e-mail: plfernandez.germanstrias@gencat.cat 